\title{
Recurrence Prevention Model in Clients with Mental Disorder Reviewed from Family Aspects
}

\author{
Dyah Widodo \\ Program Diploma III of Nursing, Politeknik Kesehatan Kemenkes Malang Indonesia
}

\begin{abstract}
According to World Health Organization, the number of clients with mental disorders will continue to Increase until it Reaches 450 million people worldwide in 2013. The number of mental disorders from the Basic Health Research in 2013 found East Java 2.2 per mile are in fourth place in severe mental disorder Indonesia. Client care of mental disorders so it takes patience, the role of the family is very important because of the family is the key to development and progress of the client. The general objective of the research is to find a model of prevention of recurrence in clients with mental disorders from the family aspect. This type of study design was cross-sectional, with a sample of some families who live with mental illness in East Java clients Appropriate inclusion criteria, with a sample size of 205 people taken by consecutive sampling technique. Time data collection on October-November 2016 in the outpatient Clinics of Mental Health Hospital Radjiman Wediodiningrat Lawang. Collecting data using a questionnaire which is based on the theory of Imogene M. King. Data analysis using SEM path analysis test with an alpha of 0.05. The result showed causal pathway Model of prevention of recurrence that: 1) Line indirect interaction effect on the prevention of relapse, as it passes communication variables; 2) Line of time there are two paths that is directly to the prevention of recurrence and indirect pathways thr o ugh the role of the family; 3 ) Line perception indirect effect on the prevention of recurrence, because it should be the role of the family. The role of the family have the most powerful influence among the other variables in the prevention of recurrence $w$ ith the estimated value of 0634. Suggested models on the prevention of mental disorders of the family, especially the role of The family, interaction and communication that is based on the perception of the condition of mental disorders as well as the availability of family time for the client.
\end{abstract}

Keywords: models, prevention, mental-disorder, family

\section{Introduction}

Mental disorder is a psychological syndrome or pattern of clinically occurs in a and associated with distress, disability or accompanied by an increased risk of a painful death and loss of freedom (Videbeck, 2008: 4). According to WHO, the number of people with mental disorders will continue to rise until it reaches 450 million people worldwide in 2013. The number of mental disorder expressed from the Basic Health Research 2013 ng tent a severe mental disorder prevalence in Indonesia that the prevalence of severe mental disorders nationally by 1.7 per mil, with the highest prevalence of psychosis in Yogyakarta and Aceh (respectively 2.7 per mil), while the lowest in West Kalimantan 0.7 per mil, while the East Java was 2.2 per mil is fourth. According to the data, it can be seen that East Java is ranked high for the problem of mental disorders in Indonesia. The high number of deprivation in East Java is due to several factors, among others, cultural factors in society that consider people with mental disorders as family disgrace, economic factors, and the inability of families to provide treatment. Deprivation prevalent in rural areas as poor as Ponorogo, Terri, Magetan, Pacitan Nganjuk, until Bojonegoro (http://bappeda.jatimprov.go.id.2014 ). Shelter in general occurs due to the inability of the family in overcoming the recurrence or recurrence of mental disorders, in addition to the family is also embarrassed by the environment or surrounding communities. This condition will actually increase the severity of the client's mental disorder condition.

Family is a context in which individuals begin an interpersonal relationship, the family can affect values, beliefs, attitudes, and behaviors of patients and families have basic functions such as giving love, a sense of security, to belong, and to prepare the individual adult role in society. If
Family is viewed as a system, then mental disorder in one family member will disrupt all system or family circumstances (Abdul Nasir, 2011: 286). Not always all the family members were able to adapt well to any problem occurring within the family, the result of mental health problems occur. In the maintenance of family members with mental disorders can not be separated from the family because of good support from the family such as information support, motivation, instrumental to increasing the development of physical, intellectual, and emotional patients will also affect the independence of ADL (Activity Daily Living) patients includes the ability to care for themselves and meet their basic needs.

Impact experienced by families as a result of a family member with a mental disorder such as a family experience a sense of discomfort, frustration, anxiety, despair, grief, fatigue and helplessness because it has been the loss of time during their routine maintenance and Treatment of patients, consequently arise family rejection of patients who tend to blame people with mental disorders resulting in lack of support to patients (Nuraenah, 2012: 24 and Abdul Nasir, 2011: 16). Someone who has a mental disorder lack of support from the family can have an impact for the patients themselves are impaired activities of daily living such as the ability to care for themselves and meet the basic needs of the less (bath, defecation / urination, eat, make up And mobilization), if this condition continues it can cause physical diseases such as hunger, malnutrition, skin diseases, gastrointestinal and respiratory infections and other diseases.

In the treatment of mental patients require patience, especially for caregivers and families, the role of the family is very important in caring for family members when completed hospital treatment because the family is the key to development and progress of patients (Ratchaneekorn 


\section{International Journal of Science and Research (IJSR) \\ ISSN (Online): 2319-7064}

Index Copernicus Value (2015): 78.96 | Impact Factor (2015): 6.391

Kertchok, et al., 2011: 39). Friedman, 2010 in Nuraenah (2012: 46) states that the family is obliged to provide the fulfillment of basic needs and optimize the peace of mind to patients with mental disorders require treatment for long enough, so that understanding and family cooperation is very important in the treatment.

Some previous research results related to this title as follows: 1) by Kartika (2010) there was a significant relationship between family support with the success of social functioning in patients with post-patient at the Mental Hospital Menur Surabaya; 2) Nuraenah (2012) finds a connection between family support (information support, emotional, instrumental and judgment) and family burden in caring for members with a history of violent behavior in the East Jakarta Klender Muslim Mental Hospital. From both studies indicate that there is a close relationship between the family with mental health conditions in patients with mental disorders.

Data from PKJ (Poly Mental Health) at Wediodiningrat Dr.Radjiman Hospital in Lawang from January to October 2014 showed that, list the number of mental patients visit to the poly soul reaches 13021 people. New patients numbered 660 people and outpatient / inpatient numbering over 12359 people will certainly continue to grow until the end of 2014. Patients with mental disorder are much dominated by men who reached 8022 amounted to 4,999 patients and female patients with a variety of diagnoses. Of those patients known to many as 4,950 patients who use public services, patients use the services of BPJS treatment (Social Security Agency), and 268 patients using APBD (Regional Budget).

Based on the above problems it is necessary to do research on the "Model prevention of recurrence in clients with mental disorders from the family aspect".

Public Interest Research is Finding relapse prevention models in clients with mental disorders from the family aspect. The aim in particular is to identify exogenous variables (which include: family perception, space, clients development, family interaction, and transaction time) and endogenous variables (which include stress, communication and the role of the family) that contribute to the prevention of relapse of psychiatric disorder clients and create a model of causality pathway recurrence prevention in clients with mental disorders from the aspect of family.

The benefits of the research is as basic health promotion in order to prevent recurrence prevention in clients with mental disorders from the family aspect.

\section{Methods}

This is cross sectional whose meanings are each subject only once in the observation and measurement of sub variables carried out during the examination. Measurements were made on aspects be related with prevention of recurrence in clients with mental disorders from the family aspect. The population in this study is the entire family who live with mental disorders in East Java who accompany client control in Mental Health Poly at Dr. Radjiman Wediodiningrat Hospital in Lawang, where the average per month for existing and new patients is 1,600 people.

The sample in this study is a part of the population that comply with the inclusion criteria as follow

1) One of the family members of people with mental disorders, namely in the area of East Java who was delivering the client controls in Mental Health Poly RSJ Dr. Radjiman Wediodiningrat Lawang (father / mother / child).

2) Age $>17$ years

3) Live with people with mental angguan $g$

4) Willing to be a respondent.

The determination of the samples in this study using a table of Sugiono (2010), where for the corresponding population estimates inclusion criteria 500 people and a $5 \%$ significance of the samples obtained 205 people. The sampling technique used Consecutive sampling method that gives the same probability for each element in the population to be selected but adapted to the purpose of research.

Data collection instrument was the questionnaire that was valid and reliable. The data collection was conducted in Mental Health Poly RSJ Dr. Radjiman Wediodiningrat Lawang October-November 2016, with attention to the rules of conduct of the study.

The hypothesis of this study that there is a causal pathway model fit the prevention of recurrence of the exogenous variables include family perception, space, growth and development of the client, the interaction within the family, time and transaction and endogenous variables that include stress, communication and family roles.

If the statistical data, ie $\mathrm{u}$ ji descriptive statistics frequency and cross tabulation, and SEM path analysis with an alpha of 0.05 .

\section{Result}

In the description of the results of this study are presented general data of respondents and the identity of the client's identity a mental disorder, and specific data on aspects of endogenous and exogenous variables as well as new findings relapse prevention model of mental disorders from the family aspect, as follows:

Table 1: Respondent Identity (Family Client Mental Disorder)

\begin{tabular}{|c|c|c|}
\hline No & Identity of Respondents & Results \\
\hline 1 & Gender & Women 52\%; Male 48\% \\
\hline 2 & Age & Average 48.47 years \\
\hline 3 & School & Elementary School 44, 88\% \\
\hline 4 & Work & Private 59\% \\
\hline 5 & Income & An average of IDR 1.37 Million \\
\hline 6 & Religion & Islam 96\% \\
\hline 7 & Tribe & Parents 54.1\% \\
\hline 8 & Family relationship & $16 \%$ \\
\hline 9 & $\begin{array}{c}\text { Having more than 1 family } \\
\text { member with mental } \\
\text { disorders }\end{array}$ & \\
\hline
\end{tabular}

\section{Volume 6 Issue 7, July 2017 www.ijsr.net}




\section{International Journal of Science and Research (IJSR) \\ ISSN (Online): 2319-7064 \\ Index Copernicus Value (2015): 78.96 | Impact Factor (2015): 6.391}

According to the table No. 1, it is known that the majority of respondents were women with an average age of adult medium has 6 six years of basic education) who are parents of clients have mental disorder.

Table 2: Client Identity of Mental Disorders

\begin{tabular}{|c|c|c|}
\hline No & Client Identity & Research result \\
\hline 1 & Gender & Male $68 \%$; Women $32 \%$ \\
\hline 2 & Age & Average 34.2 years \\
\hline 3 & Education & an average of 9.2 years \\
\hline 4 & Work & Did not work $62.4 \%$ \\
\hline 5 & Religion & Islam $96.1 \%$ \\
\hline 6 & Tribe & Java $96.6 \%$ \\
\hline 7 & $\begin{array}{c}\text { The age of first Mental } \\
\text { Disorder }\end{array}$ & 24,8 years \\
\hline 8 & Old mental disorders & An average of 9,5 years \\
\hline 9 & $\begin{array}{c}\text { The frequency of } \\
\text { hospitalization in RSJ }\end{array}$ & An average of 2.6 times \\
\hline
\end{tabular}

According to the table no 2 note that the majority of the clients are male middle-aged adults who have long suffered mental disorders (9.5 years) and had a relapse on average more than 2 times in-patient at the Mental Hospital.

Table 3: Endogenous variables contributing to Recurrence Mental disorders

\begin{tabular}{|c|c|c|c|c|}
\hline No & Aspects of Variable Endogenous & \multicolumn{3}{|c|}{ Research result } \\
\cline { 3 - 5 } & $\begin{array}{c}\text { Good } \\
(\%)\end{array}$ & $\begin{array}{c}\text { Moderate } \\
(\%)\end{array}$ & $\begin{array}{r}\text { Less } \\
(\%)\end{array}$ \\
\hline 1 & $\begin{array}{c}\text { Family Perception Against Client } \\
\text { Mental Disorders }\end{array}$ & 0 & 74.1 & 25.9 \\
\hline 2 & $\begin{array}{c}\text { Space Availability at Home For } \\
\text { Clients at Home }\end{array}$ & 8 & 81 & 18.5 \\
\hline 3 & Categories of Growing Clients & 58.5 & 37.1 & 4.4 \\
\hline 4 & $\begin{array}{c}\text { Interaction Client Family With Menta } \\
\text { Disorder in the House }\end{array}$ & 79.5 & 19.0 & 1.5 \\
\hline 5 & $\begin{array}{c}\text { Family Time For Clients With Life at } \\
\text { Home }\end{array}$ & 15.1 & 66.8 & 18.1 \\
\hline 6 & $\begin{array}{c}\text { Health Service Transactions for Client } \\
\text { Mental Disorders }\end{array}$ & 37.1 & 62.4 & 5.0 \\
\hline
\end{tabular}

Based on table no 3 it can be seen that the majority of respondents have sufficient perception about mental disorders, space facilities at home and time for clients. Besides, clients receive health care is quite good, and developmental aspect of clients and interaction with the family well.

Table 4: Exogenous Variables of Stress Contributing to Recurrence Mental disorders

\begin{tabular}{|l|l|c|c|c|}
\hline No & Aspects of Exogenous Variables & \multicolumn{3}{|c|}{ Research result } \\
\cline { 3 - 5 } & & $\begin{array}{r}\text { High } \\
(\%)\end{array}$ & $\begin{array}{c}\text { Medium } \\
(\%)\end{array}$ & $\begin{array}{r}\text { Low } \\
(\%)\end{array}$ \\
\hline 1 & Family Stress On Nuisance Client & 11.7 & 17.6 & 71.2 \\
\hline
\end{tabular}

Based on table no 4 it can be seen that respondents of family mental disorder majority have low stress.

Table 5: Exogenous variables Contributing to Recurrence Mental disorders

\begin{tabular}{|c|c|c|c|c|}
\hline No & Aspects of Exogenous Variables & \multicolumn{3}{|c|}{ Research result } \\
\cline { 3 - 5 } & $\begin{array}{c}\text { Good } \\
(\%)\end{array}$ & $\begin{array}{c}\text { Moderate } \\
(\%)\end{array}$ & $\begin{array}{c}\text { Less } \\
(\%)\end{array}$ \\
\hline 1 & $\begin{array}{c}\text { Family Communication With } \\
\text { Client Mental Disorders at Home }\end{array}$ & 26.8 & 71.2 & 2.0 \\
\hline 2 & $\begin{array}{c}\text { The Role of Families for Life- } \\
\text { Mental Clients at Home }\end{array}$ & 36.6 & 63.4 & 0 \\
\hline 3 & $\begin{array}{c}\text { Prevention of Client Disease } \\
\text { Recurrence at Home }\end{array}$ & 32.2 & 66.3 & 1,2 \\
\hline
\end{tabular}

According to the table no 5 known that the majority of respondents families quite well in communication with clients, the role and actions of recurrence prevention of mental disorders. Then presented findings on Relapse Prevention Model disorders soul:

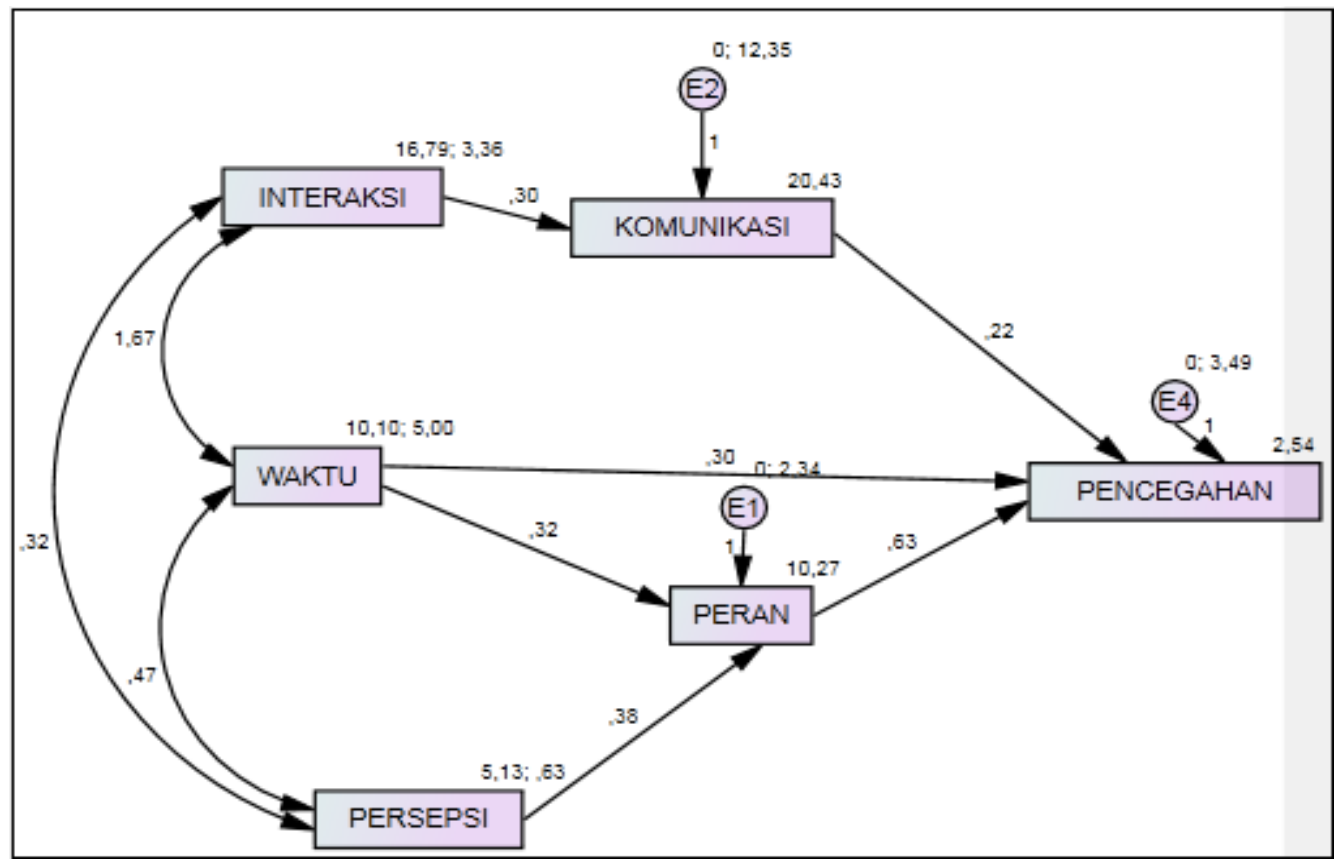

Figure 1: Model of Mental Disorder Prevention from Family Aspect

Volume 6 Issue 7, July 2017 www.ijsr.net

Licensed Under Creative Commons Attribution CC BY 


\section{International Journal of Science and Research (IJSR) \\ ISSN (Online): 2319-7064}

Index Copernicus Value (2015): 78.96 | Impact Factor (2015): 6.391

This model is a new finding obtained from circuit analysis, after statistically verified can be seen there are three pathways that influence of exogenous variables, namely:

1) Hiking interaction indirect effect on the prevention of recurrence, because it passes through the communication endogenous variables.

2) Time paths are two paths that are directly against the prevention of recurrence and the indirect path through the family role

3) Influence perception pathway indirectly to the prevention of recurrence, because it should be the role of the family

The family role has the strongest influence among other variables in the prevention of recurrence with an estimated value of 0.634 .

\section{Discussion}

Exogenous Variable contributing to the prevention of recurrence clients with mental disorders clients include family perception, space, fall, family interaction, and transaction time.

Family perception was measured from the aspect of knowledge about the signs, causes and treatment of mental disorders $74.1 \%$ sufficient. According to Christensen JP (2009), perception is defined as a person's description of reality, perceptions related to past experience, self-concept, socioeconomic, genetics and educational background. In this study the respondent's perception is primarily associated with mental disorders. According to (Act No. 3 of 1966) is a state of mental disorder disturbance in mental functions, which include; Process of thinking, emotion, willingness and psychomotor behavior including speech (Abdul Nasir, 2011: 8 ). The perception of mental illness is likely to be supported by the majority of respondents education factor is air basic education (primary $\mathrm{d}$ an SMP) is $64.39 \%$; even $3.9 \%$ of them have never been to school at all.

In order to improve the independence of clients in en, optimization role in society and to improve its ability to solve problems. it is necessary for family role to help meet the needs appropriate stages of the independence of the client (Abdul Nasir, 2012). From the aspect of the room amenities provided by the families to the client $81 \%$ adequate, although the majority of families in the category of medium or economic ability is low. According to Abdul Nasir (2012: 32) people with low socioeconomic status, less active and more fatalistic or refused response when compared with people who have a high socio-economic status. The socioeconomic status of a person is not based solely on income but also includes certain factors such as education, employment and lifestyle. Gerald C, (2006: 469) says there is a positive relationship between socio status Economic and mental health, thus people with socioeconomic status High economy has better mental health than people with socio-economic status Low economy. More than half or $58.5 \%$ of client growth is measured by the ability to carry out daily activities and socialization activities are good. The daily activities at home is a form of therapy that is useful for clients. Families need to give sufficient role in the client according to the client's ability level. Giving the appropriate role can increase the client's self-esteem.
Motivation in accordance with the needs of the client is beneficial to improve the morale and self-esteem. The ability which has been owned by the client in the past need to be developed because it is useful to stimulate and improve the function of the client (Abdul Nasir, 2012).

The family is a collection of two or more persons living together by blood, marriage relationship with an emotional attachment as well as the rules and have the respective roles that are part of the family. As the smallest unit in society (PP No. 21 of 1994), the family has 5 (five) basic functions which one of them is affective function. Affective functions, namely the function of the family for develop and maintenance of children's personality, personality of adults, as well as the fulfillment of the psychological needs of its members. If this affective function does not work properly then it will have a psychological disorder that affects the mental state of the entire family unit Friedman (1998; in Abdul Nasir, 2011: 283). The function of socialization is the process of interaction with the social environment that begins at birth and ends after death. Family members learn discipline, culture, norms through interaction within the family so that individuals can play a role in society. Failure to socialize in the family, especially if norms and learned behaviors different from those in the community can lead to failure bers o socializing in the community (Friedman (1998; in Suprajitno, 2004: 13).

The results showed that $62.4 \%$ of health care transactions for clients with mental disorders that have been obtained is sufficient. Transactions are defined as interactions that have a particular purpose in achieving the goal (Christensen JP, 2009). With a good service from the Hospital then the mental health condition will continue to optimal because all the needs for treatment and care can be met well.

Endogenous variable contribute to the prevention of recurrence of mental disorders from the family aspect is stress, communication and family roles. Conditions of stress on family respondents turned out $71.2 \%$ of mental disorders is a low stress. This possibility occurs because the family has adapted to the condition of the client who on average has more than 9 years of mental disorders.

From the description can be understood that in conducting interpersonal relationships, a person must not be separated from the stress conditions. Light stress owned by respondents shows that the family has been able to adapt to the existence of clients who have suffered mental disorders an average of 9.4 years with the frequency of hospitalization on average more than 2 times. This light stress is also beneficial for families to always be wary of the possibility of recurrence in the client mental disorders.

The communication is done on the client family according to the respondents was $71.2 \%$ sufficient. Communication is defined as a process of delivering information from someone to others directly or indirectly. Verbal and non verbal communication in family relationships has a very important meaning. Sometimes clients mental disorders have a higher sensitivity in capturing non-verbal communication. If the communication goes well enough then it will provide a conducive relationship climate in the family.

\section{Volume 6 Issue 7, July 2017 www.ijsr.net}




\section{International Journal of Science and Research (IJSR) \\ ISSN (Online): 2319-7064}

Index Copernicus Value (2015): 78.96 | Impact Factor (2015): 6.391

Sources of internal family support, such as the support of his / her spouse, support of siblings, the support of the child and family support such external support from friends, neighbors, schools, large families, places of worship, health practitioner , Friedman (1998; in Nurainah, 2012: 50)

Model fit causality track prevention of recurrence was found that the interaction groove indirect effect on the prevention of recurrence, because it passes through the communication endogenous variables. The results showed that use values to estimate the interaction of communication is the beta value, the regression coefficient $(0.296)$, while the intercept is a constant (20.429). No communication was the one variable that affects the interaction with 0.023 ; By the way the same calculation, it can be said interaction variables can explain the communication of $2.3 \%$ the rest $97.7 \%$ explained by other variables. Spark plug is very small, but because of the significance value, still must be interpreted to give effect to the communication interaction.

The results showed that the time slot $\mathrm{j}$ there are two paths that is directly against the scum prevention harbor and indirect pathways through the role of the family. The results also show the groove $\mathrm{j}$ perception indirect effect on the prevention of recurrence, because it should be the role of the family. Variable prevention of recurrence is variable endogen Lastly, as the result of the many variables, after the selection of variables statistically, there are three influential variable family roles, timing and communication with determination coefficient 0,467 , meaning that the variable role out $\mathrm{g}$ a and communication can explain variable $\mathrm{p}$ Flood protection recurrence of $46.7 \%$, the remaining $53.3 \%$ is explained by other variables. Direct effects are shown by direct arrows of the major endogenous variables: prevention of recurrence. There are three main variables, namely communication, time and family roles. Variable family roles that directly influence the prevention of recurrence, including most is 0.433 . W ith so to prevent a recurrence of the most effectively utilize a more family an optimal.

The main assumption in the theory of King states, the environment is every social system in society; The social system is a dynamic force that affects social behavior, integration, perception, and health, such as hospitals, clinics, community institutions, and industry characteristics of Imogene King's theory (Christensen \& Kenney, 1995). Similarly, the family environment, which also has a dynamic force in affecting one's health. From the research results can be seen that especially communication in the family and the role of the family can directly affect the prevention of recurrence in the client mental disorders.

The interpersonal system characteristic of Imogene King's theory (Christensen \& Kenney, 1995) is two or more individuals or groups that interact. This interaction can be understood by looking further at the role of family mental disorders, interactions, communication, transactions, stress and coping by the family in caring for clients at home.

\section{Conclusions}

The exogenous variables that include family perception as measured from the aspect of knowledge about the signs, causes and treatment of mental disorders $74,1 \%$ enough indoor facilities for clients $81 \%$ enough, more than half, or $58.5 \%$ growth as measured by the ability of the client to do daily activities and socialization is good, the interaction in the family $79.5 \%$ good, time available for client families $66.8 \%$ and $62.4 \%$ of transactions sufficient health services for clients with mental disorders that have been obtained ad a lah enough.

Endogenous Variable include stress $71.2 \%$ lower , communications $71.2 \%$ fairly and family roles that contribute to the prevention of relapse of psychiatric disorder $63.4 \%$ clients fairly. As for the prevention of recurrence of mental disorder clients at home majority or $66.3 \%$ is enough. Model fit causal pathways prevention of recurrence was found that: Hiking interaction indirectly effect on the prevention of recurrence, because it passes through the communication endogenous variables.

There are two pathways that are directly to prevention of recurrence and indirect pathways through the role of the family. Hiking perception indirectly effect on the prevention of recurrence, because it should be the role of the family. The role of the family have the most powerful influence among the other variables in the prevention of recurrence with the estimated value of 0.634 .

\section{References}

[1] Arikunto, S. 2002. Prosedur Penelitian Suatu Pendekatan Praktek. Jakarta : Rineka Cipta.

[2] Boyd \& Nihart. (1998). Psychiatric nursing Contemporary practice. Philadelphia: Lippincoat Raven Publisher.

[3] Christensen, Paula J. (2009) : Nursing Process:Aplication of Conceptual Models, 4th ed. St.Louis: Mosby-Year Book, Inc.

[4] Dirjen Binkesmas Depkes RI. (2003). Buku Pedoman umum: TPKJM tim Pembina, pengarah dan pelaksana kesehatan jiwa masyarakat. Jakarta: Depkes RI

[5] Irawan , P. (2006). Penelitian kualitatif \& Kuantitatif untuk ilmu-ilmu sosial. Depok: Departemen Imu Administrasi FISIP UI

[6] Magliano,L. (2008). Families of People with severe mental disorders: difficulties and resources. http//www.euro.who.int/document/MNH/familyburden. Diakses tanggal 2 Januari 2009

[7] Mohr, W. K. (2006). Psychiatric mental health nursing. (6 th ed.). Philadelphia: Lipincott Williams Wilkins.

[8] Perry \& Potter. 2005. Fundamental of Nursing, Concept, Process, and Practice: Edisi 4, Penerbit Buku Kedokteran EGC: Jakarta

[9] Sugiono. (2010). Metode Penelitian. Bandung: Albeta

[10] Stuart, G.W., \& Laraia M.T. (2005). Principles and practice of psychiatric nursing, $\left(8^{\text {th }} e d\right)$, St. Louis: Mosby.

[11] Townsend, C.M. (2003). Psychiatric mental health nursing concept of care fourth edition. Philadelphia: F.A. Davis Company

[12] ........... Teori Imogene M. King, 2016,

[13] http://nursingscience-

2008.blogspot.co.id/2014/12/riwayat-hidup-imogenem-king.html, diakses 16 Agt 2016 pkl 08.35 WIB

\section{Volume 6 Issue 7, July 2017 www.ijsr.net}

